\title{
A Case of Hepatitis B Virus Related Membranous Glomerulonephritis That Well Responsed to Low Dose Corticosteroid Therapy
}

\author{
Düşük Doz Kortikosteroid Tedavisine İyi Yanıt Veren Hepatit B Virüs \\ iliş̧kili Membranöz Glomerülonefrit Vakası
}

Bennur ESEN ${ }^{1}$, Ahmet Engin ATAY ${ }^{1}$, Hasan KAYABAŞI ${ }^{1}$, Kamile Gülçin EKEN², Dede ŞIT ${ }^{1}$

${ }^{1}$ Department of Internal Medicine, Bağcilar Training and Research Hospital, Istanbul, Turkey

${ }^{2}$ Department of Pathology, Şişli Etfal Training and Research Hospital, Istanbul, Turkey

Glomerulonephritis (GN) is a common extrahepatic manifestation of chronic hepatitis B virus (HBV) infection, affecting approximately $20 \%$ of patients from the Middle East and Far East Asia, where HBV infection is prevalent (1) Recent data show that $30 \%$ of patients with HBV-related GN eventually progress to renal failure (2). The major pathogenetic mechanism of HBV-related GN is immune complex deposits in the kidney, leading to destruction of the epithelial side of the glomerular basement membrane and eventually resulting in protein loss into the tubules. Although treatment strategies of HBV and membranous nephropathy are well established, there is still a lack of available data in patients who not respond well to primary intervention or who have failed to sustain the response.

A 48-year-old man was admitted with edema in his lower extremities lasting for 3 days while he was receiving interferon (IFN) plus lamivudine for 5 months. The biochemical and urine analysis revealed hypoalbuminemia $(1.9 \mathrm{mg} / \mathrm{dl})$, proteinuria $(+++)$ ( $6.2 \mathrm{gr} /$ day), and hematuria. On serologic examination, he had markedly elevated HBV surface antigen (HBsAg) and HBV DNA counts. He underwent a renal biopsy due to persistent proteinuria in the fifth week of admittance. Immunofluorescence (IF) examination of the renal biopsy pointed out a diffuse granular capillary wall and glomerular basement membrane thickening, with immune complex deposits along the glomerular capillary wall (Figure 1-3). Viral antigen was also identified in the glomeruli by IF. Oral prednisolone, at a dose of $40 \mathrm{mg} / \mathrm{day}(0.6 \mathrm{mg} / \mathrm{kg} / \mathrm{day})$, was initiated, and after improvement in his clinical status and laboratory examination (decreased proteinuria, elevated albumin level), corticosteroid therapy was gradually tapered and terminated. At the 6-month follow-up, he was free of symptoms, and the urine protein loss decreased to $27 \mathrm{mg} /$ day. Written consent was obtained from the patient.

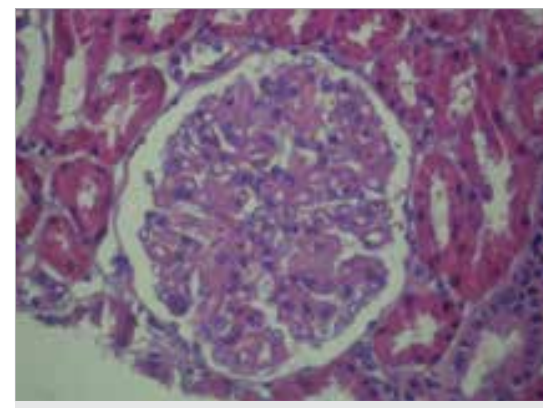

Figure 1. Diffuse thickening of the capillary basal membrane and mild mesangial proliferation ( H\&E stain)

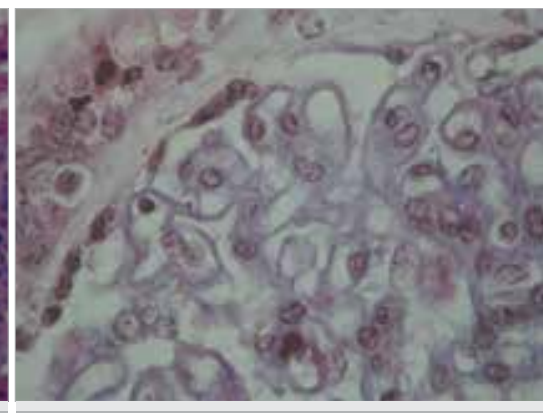

Figure 2. The subepithelial deposits in capillary wall are stained red with trichrome stain

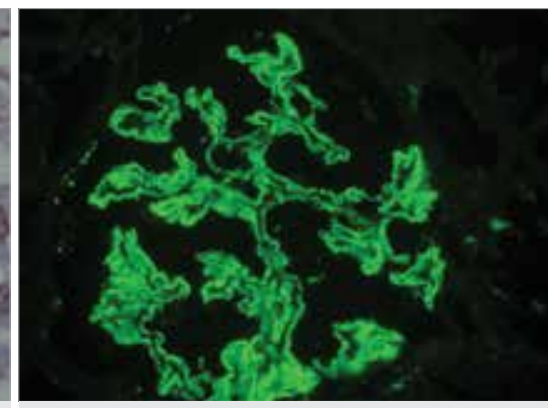

Figure 3. Subepithelial and little mesangial granuler deposits in glomeruli (Anti lgG FITC)

Address for Correspondence / Yazışma Adresi: Bennur Esen; Department of Internal Medicine, Bağcllar Training and 
Overall remission and sustained remission rates of proteinuria by antiviral therapy are $60 \%$ and $50 \%$, respectively (3). The primary outcomes of antiviral combined corticosteroid therapy are undetectable HBV DNA, normal ALT level, and disappearance of proteinuria. Panonsak et al. reported that the remission rate of proteinuria after corticosteroid monotherapy and antiviral monotherapy is $75 \%$ and $28.6 \%$, respectively (4). Another meta-analysis by Zheng et al. determined that combined corticosteroid and antiviral therapy achieved a proteinuria remission rate of $89 \%$ (5). Also, Zheng et al. (5) showed that low-dose steroid therapy had similar beneficial effects in reducing proteinuria and elevating albumin as high-dose steroid therapy, without increasing the risk of viral replication. However, there are still limited data to compare combined antiviral-immunosuppressant therapy with antiviral or corticosteroid monotherapy.

Informed Consent: Written informed consent was obtained from patients who participated in this study.

Peer-review: Externally peer-reviewed.

Author Contributions: Concept - B.E., A.E.A., D.S.; Design - B.E., A.E.A.; Supervision - B.E., D.S.; Funding - B.E., D.S., H.K.; Materials - D.E., K.G.E.; Data Collection and/or Processing - B.E., A.E.A, D.S.; Analysis and/ or Interpretation - A.E.A., D.S.; Literature Review - B.E., D.S.; Writing A.E.A., D.S.; Critical Review - D.S., H.K.

Conflict of Interest: No conflict of interest was declared by the authors.

Financial Disclosure: The authors declared that this study has received no financial support.
Hasta Onamı: Yazılı hasta onamı bu çalışmaya katılan hastalardan alınmıştır.

Hakem Değerlendirmesi: Dış bağımsız.

Yazar Katkıları: Fikir - B.E., A.E.A, D.S.; Tasarım - B.E., A.E.A.; Denetleme - B.E., D.S.; Kaynaklar - B.E., D.S., H.K.; Malzemeler - B.E., K.G.E.; Veri Toplanması ve/veya İşlemesi - B.E., A.E.A., D.S.; Analiz ve/veya Yorum A.E.A., D.S.; Literatür Taraması - B.E., D.S.; Yazıyı Yazan - A.E.A., D.S.; Eleştirel İnceleme - D.S., H.K.

Çıkar Çatışması: Yazarlar çıkar çatışması bildirmemişlerdir.

Finansal Destek: Yazarlar bu çalışma için finansal destek almadıklarını beyan etmişlerdir.

\section{Kaynaklar}

1. Terrier B, Cacoub P. Hepatitis B virus, extrahepatic immunologic manifestations and risk of viral reactivation. Rev Med Interne 2011; 32: 622-7. [CrossRef]

2. Bhimma R, Coovadia HM. Hepatitis B virus-associated nephropathy. Am J Nephrol 2004; 24: 198-211 [CrossRef]

3. Fabrizi F, Dixit V, Martin P. Meta-analysis: anti-viral therapy of hepatitis B virus-associated glomerulonephritis. Aliment Pharmacol Ther 2006; 24: 781-8. [CrossRef]

4. Panomsak S, Lewsuwan S, Eiam-Ong S, Kanjanabuch T. Hepatitis$B$ virus-associated nephropathies in adults: a clinical study in Thailand. J Med Assoc Thai 2006; 89: 151-6.

5. Zheng XY, Ri-Bao Wei RB, Tang L, Li P, XZheng XD. Meta-analysis of combined therapy for adult hepatitis $\mathrm{B}$ virus-associated glomerulonephritis. World J Gastroenterol 2012; 28: 821-32. [CrossRef] 